\title{
Contribution to the knowledge of the pseudoscorpion fauna of the North-Eastern Carpathians, Ukraine (Arachnida: Pseudoscorpiones)
}

\author{
J. NovÁK
}

János Novák, Eötvös Loránd University, Department of Systematic Zoology and Ecology, H-1117

Budapest, Pázmány P. sétány 1/C, Hungary.E-mail: novakjanos01@gmail.com.

\begin{abstract}
Investigating the soil samples of the Hungarian Natural History Museum collected in the North-Eastern Carpathians, a total of six species belonging to two families were found. One of them, Neobisium brevidigitatum (Beier, 1928 ) is new for the fauna of Ukraine; a brief description of the new specimen is given. The pseudoscorpion species reported earlier from the region are briefly summarized. According to these new and the preceding literature data the pseudoscorpion fauna of Ukraine now counts twenty-six species.
\end{abstract}

Keywords. pseudoscorpions, Ukraine, faunistics, new records, soil fauna.

\section{INTRODUCTION}

The pseudoscorpion fauna of Ukraine is one of the least studied in Europe - the online catalogue of Harvey (2013) lists only 22 species from the country, although many more are likely to occur. This is particularly so for the mountainous western part of Ukraine that covers the North-Eastern Carpathians (Fig. 1). This mountain range is a biodiversity hotspot in the heart of Europe and widely known for high species richness and local endemism (Mráz \& Ronikier 2016). The area was studied for pseudoscorpions several times in the last 140 years (Daday 1888, Rafalski 1937, Hadži 1939, Szent-Ivány 1941, Schawaller 1989) but our knowledge of its fauna is still fragmentary.

This part of the Carpathians comprises five distinct mountain areas: the Beskid, Gorgan, and the Maramaros Mountains, the Polonines Mounts and the Vihorlat-Gutin Mountain area. From a geographical point of view, elements of the North-Eastern Carpathians also extend into Eastern Slovakia and Northern Romania. However, only the Ukrainian part of the area is discussed here for practical reasons.

Only a handful of faunistic and taxonomic studies have documented pseudoscorpions here. The first record was established by Daday (1888) who reported three species: Neobisium sylvaticum (C. L. Koch, 1835) (as N. dumicola) from the Ivan Pop Mountain, Rhacochelifer peculiaris (L. Koch, 1873) (as Chelifer peculiaris) and Neobisium carcinoides (Hermann, 1804) (as Obisium carcinoides) from Galambos village (in Ukranian Голубине).

Almost a half century later, N. polonicum Rafalski, 1937 was described from numerous localities between the area of the Cheremosh and San rivers; some of them situated in the outer arch of the North-Eastern Carpathians in Ukraine [Horod (Город); Jaremcse (Яремче); Schronisko w dolinie Świcy; Vorohta (Bopoxta))] (Rafalski 1937).

Some years later Hadži provided new occurrences of several pseudoscorpion species from the Ivan Pop Mountain in the North-Eastern Carpathians (Hadži 1939): Chthonius heterodactylus Tömösváry, 1882 (as C. knesemani); Neobisium sylvaticum (as $N$. sylvaticum inaculeatum); $N$ carcinoides (as $N$ muscorum); $N$ carpaticum Beier, 1935 (as N. muscorum carpaticum); N. polonicum Rafalski, 1936; and Roncus transsylvanicus Beier, 1928. 


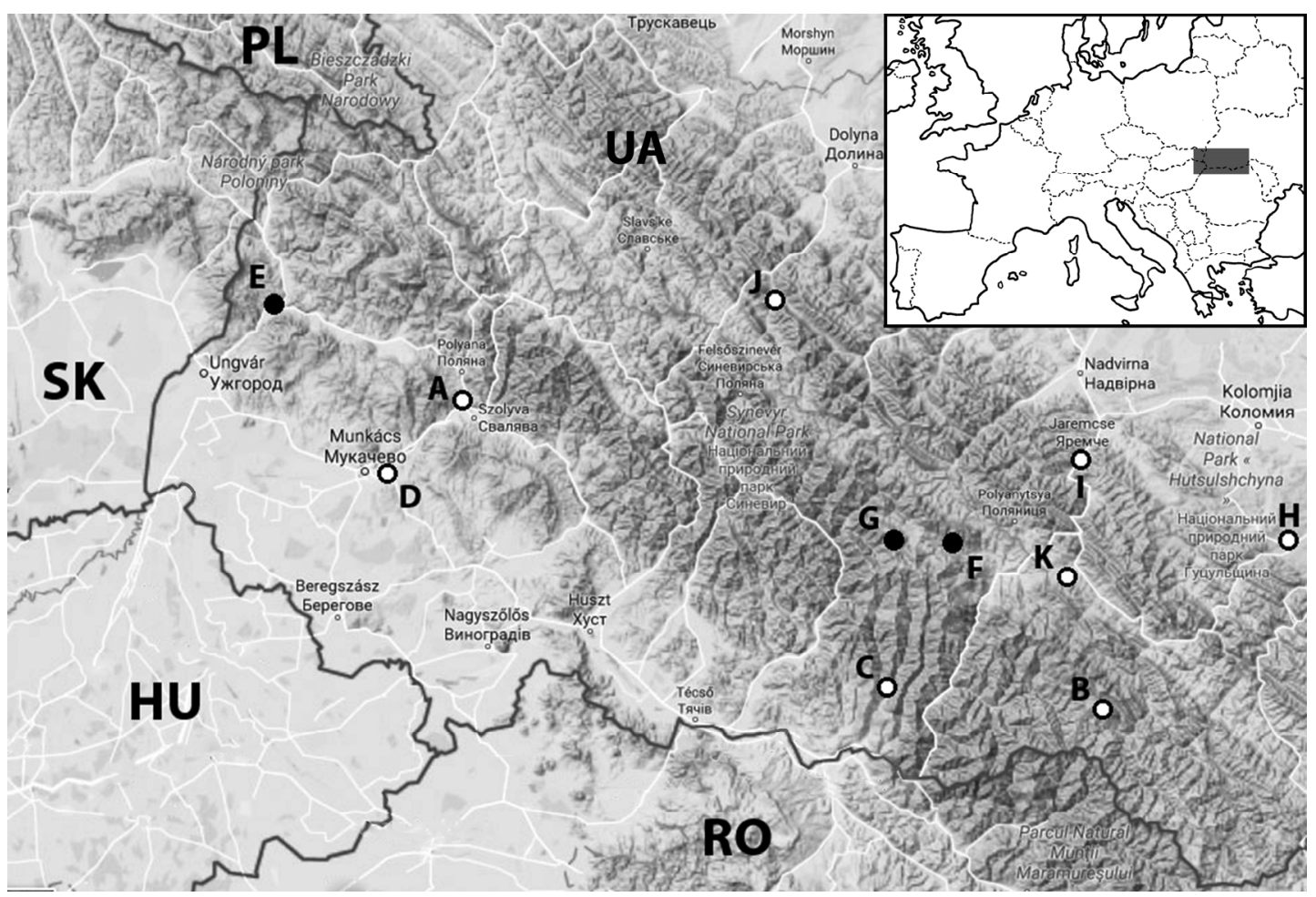

Figure 1. Collecting localities of present study (full circles) and older literature (empty circles). A = Galambos; B = Ivan Pop Mount; $\mathrm{C}$ = Gyertyánliget; $\mathrm{D}=$ Mukacheve; $\mathrm{E}=$ Perecseny; $\mathrm{F}=$ Source of Black Tisza River; $\mathrm{G}=$ =: Svidovec; $\mathrm{H}=\mathrm{Horod}$; $\mathrm{I}=$ Jaremcse; $\mathrm{J}=$ Schronisko $\mathrm{w}$ dolinie Świcy; $\mathrm{K}=$ Vorohta.

Six species were also reported from Gyertyánliget village (Кобилецька Поляна) by SzentIvány (1941): C. heterodactylus; N. fuscimanum (C. L. Koch, 1873); N. carpaticum; N. polonicum (as N. biharicum Beier, 1939 [synonymized by Novák \& Hörweg (2016)]); Lamprochernes chyzeri (Tömösváry, 1882); Chelifer cancroides (Linnaeus, 1758).

Almost 50 years later Schawaller (1989) added Mundochthonius carpaticus Rafalski, 1948; Chthonius heterodactylus (as Chthonius diophthalmus); C. tetrachelatus (Preyssler, 1790); N. crassifemoratum (Beier, 1928); N. sylvaticum and $R$. transsilvanicus from localities near to Mukacheve (Мукачеве in Ukranian and Munkács in Hungarian).

Herewith a list of pseudoscorpions from the North-Eastern Carpathians is presenter on the basis of museum material collected between 1939 and 2012. The aim of this study is to summarize our knowledge on the pseudoscorpion fauna of the North-Eastern Carpathians, by reporting the results of determination of the pseudoscorpion samples housed in the Hungarian Natural History Museum from this area.

\section{MATERIALS AND METHODS}

All specimens were collected by hand sampling, sifting and pitfall traps. Representative specimens were cleared in lactic acid and examined with a stereo- and a Zeiss Axioskop 2 compound light microscope. The specimens were identified according to the keys and descriptions of Beier (1928, 1963), Chrystophoriová et al. (2011) and Mahnert (2004) by the author. Drawings were made with the aid of a Zeiss Axioskop 2 microscope. Measurements were made with the Olympus Soft Imaging analySIS work 5.0 software. The specimens are stored in $70 \%$ ethanol and deposited in the Hungarian Natural History Museum (HNHM). All specimens 
are registered and accompanied with an inventory number (,HNHM Pseud-Nr). Unfortunately, in case of older material no exact locality data were available on the collection label. In Figure 1. not all type localities of $N$. polonicum have been marked because several of them fall outside of the region, and a couple of them could not be traced due to the outdated or dubious locality names used in the original description.

\section{RESULTS}

\section{Family Chthoniidae Daday, 1888}

\section{Chthonius (Ephippiochthonius) tetrachelatus (Preyssler, 1790)}

Locality. Perecseny (Перечин), Pliska Mts, 10.08.1944, leg.: János Balogh (HNHM Pseud1968: 1 juv.).

Remarks. The species has yet been recorded from the studied region near to Mukacheve (Schawaller 1989). Only a single juvenile specimen was found during the present investigation.

\section{Chthonius heterodactylus Tömösváry, 1882}

Localities. Black-Tisza Source, pine forest, from moss, 10.08.2012, leg: Józsefné Jely (HN HM Pseud-1965: 19); Svidovec (Свидівець), sifted from moss, 07.07.1939 (HNHM Pseud1966: 3ð); Svidovec (Свидівець), pine forest, 1300m asl., 08.1939 (HNHM Pseud-1967: 1q).

Remarks. The species is known from several localities of the North-Eastern Carpathians (Hadži 1939; Szent-Ivány 1941; Schawaller 1989). Hadži (1939) recorded it for the first time from the area as Chthonius knesemani Hadži, 1939, but this name later proved to be a junior synonym of $C$. heterodactylus (Gardini 2014). It was recently found in neighbouring Hungary (Kárpáthegyi 2006) and redescribed by Gardini (2014). Some of the newly found specimens had only one pair of praeocular setae, and one female (HNHM Pseud1965) had only a rudimentary epistome - accord- ing to Gardini (2014), these are rare, but normal character variations in case of this species.

\section{Neobisiidae Chamberlin, 1930}

\section{Neobisium brevidigitatum (Beier, 1928)}

(Figures 2A-G)

Locality. Svidovec (Свидівець), pine forest, 1300m asl. 07.1939 (HNHM Pseud-1970: 19).

Description of the specimen. Measurements (in $\mathrm{mm}$ ) and ratios (in parentheses). Body length 2.1. Carapace 0.66/0.68. Cheliceral hand: 0.41/0.24; finger: 0.27. Palpal femur: 0.84/0.25(3.36x); patella $0.62 / 0.31(2.02 \mathrm{x})$; Chelal hand $0.66 / 0.43$; pedicel 0.09; finger 0.83.

Carapace (Fig. 2A). Approximately as long as wide, smooth, epistome triangular and pointed. Two pairs of eyes with lenses. Setal formula: $\mathrm{m} 4 \mathrm{~m}: 6: 6: 6$. Two pairs of slitlike lyrifissures in the ocular region and one pair near the posterior margin.

Coxal area. Manducatory process with 6 setae, rest of pedipalpal coxa with $8-10$ setae; pedal coxa I with 9-11 setae; II: 7; III: 8; IV: 11-12. Anterolateral process of coxa I long and traingular; medial process prominent, with denticles (Fig. 2B).

Opisthosoma. Chaetotaxy of tergites I-X: 8:10:12:14:14:12:10:10:10:10. Segment XI with 10 setae, 4 of them tactile. Anal cone with 2 ventral and 2 dorsal setae. Chaetotaxy of sternites IV-X: 10:12:14:14:12:14:14. Female genital region: sternite II with 12 small setae, sternite III with 16 small setae in a row.

Chelicera (Fig. 2C). with 7 setae on hand. Spinneret prominent and rounded, with 7 hyalin ducts. Fixed finger with 13 little and medium teeth, movable with 9-10 medium teeth.

Pedipalp (Fig. 2D). Surface smooth, trochanter with tubercle. Femur 3.36, patella 2.02 times as long as broad. Chela (Fig. 2E). Pedicel with 5 dorsal micropores. Fixed chelal fingers with 63 close-set teeth of slightly unequal length (Fig. 2FG). Movable chelal finger with 54 flattened teeth. Trichobotria on chelal fingers disributed as on 
Figure 2E. Distance between trichobothria $i b$ and $i s t$ approximately twice that between $i s t$ and $i t$.

Legs. Surface smooth. Claws simple and smooth, arolia not longer than claws. Tibia IV with a medial, tarsus IV with basal, telotarsus IV with a sub-medial tactile seta.

Remarks. This is a new species for the fauna of Ukraine. The species has previously been reported from Georgia, Poland, Slovakia, and Romania (Harvey 2013), and recently from Hungary (Novák 2015). The specimen described here corresponds well with Beier's description (Beier $1928,1963)$ and with the specimens found in Hungary. However, it is evident that the species might have somewhat larger variation in morphological and morphometrical characters than noted in the literature (Beier 1963; Novák 2015). The new specimen has larger spinneret and wider chelal hand (chelal hand length/width ratio in the specimen from Ukraine: 1.48x; specimens from Hungary: $1.64 \mathrm{x}$; in Beier's description: 1.5-1.6x), and its body is smaller $(2.1 \mathrm{~mm}$ long) than in earlier descriptions $[2.5-3.5 \mathrm{~mm}$ (Beier 1963) and 2.72mm (Novák 2015)].

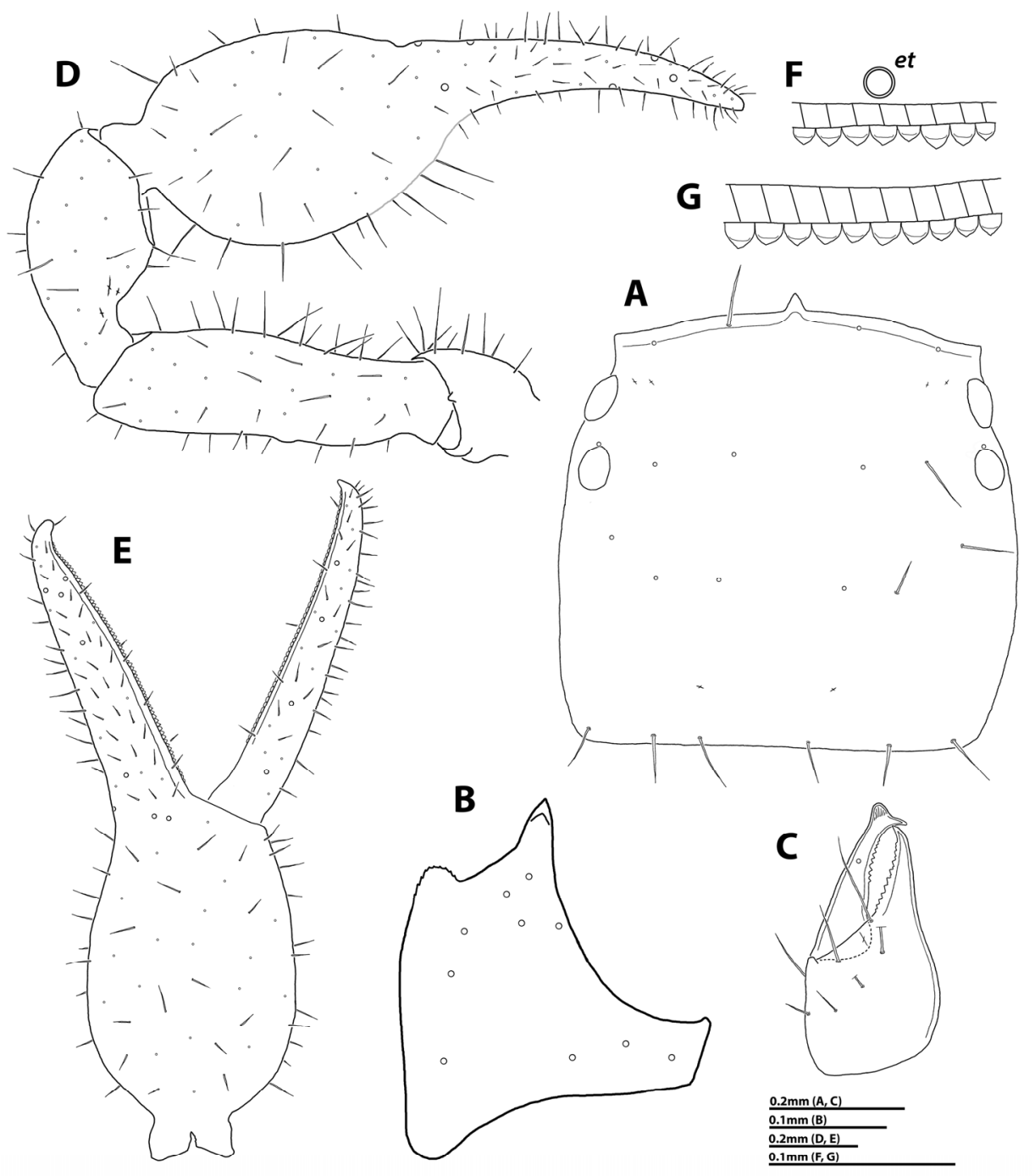

Figure 2. Neobisium (N.) brevidigitatum (HNHM Pseud-1970). A = carapace, dorsal view; B = coxa I, ventral view; $\mathrm{C}=$ left chelicera, dorsal view; $\mathrm{D}=$ left pedipalp, dorsal view; $\mathrm{E}=$ right chela, lateral view; $\mathrm{F}=$ chelal teeth of fixed Finger at the level of $e t ; \mathrm{G}=$ chelal teeth of fixed finger at the level of $i s t$. 


\section{Neobisium carcinoides (Hermann, 1804)}

Locality. Perecseny (Перечин), 10.08.1944, leg.: János Balogh (HNHM Pseud-1969: 1ㅇ).

Remarks. Common species in Europe (Harvey 2013). It was reported earlier from the studied area by Daday (1888) and Hadži (1939).

\section{Neobisium carpaticum Beier, 1935}

Locality. Perecseny (Перечин), 10.08.1944, leg.: János Balogh (HNHM Pseud-1971: 1 juv.).

Remarks. Known from Poland, Romania, Serbia, and Slovakia (Harvey 2013), with several additional records from the North-Eastern Carpathians (Hadži 1939, Szent-Ivány 1941). Only one juvenile was found during the present investigation.

\section{Neobisium crassifemoratum (Beier, 1928)}

Locality. Black-Tisza Source, pine forest, from moss, 10.08.2012, leg: Józsefné Jely (HNHM Pseud-1965: 1ठ).

Remarks. The species occurs in Middle and Eastern Europe, Anatolia and the Caucasus (Harvey 2013). Schawaller (1989) has previously recorded $N$. crassifemoratum from the region studied here.

\section{DISCUSSION}

Altogether six pseudoscorpion species belonging to two families were reported here from the North-Eastern Carpathians. Neobisium brevidigitatum (Beier, 1928) is a new record for the fauna of Ukraine. With this new record the number of the pseudoscorpion species known from the region has raised from eleven to twelve.

Five of the species reported from the study area are distributed mostly in the Carpathians $(C$. heterodactylus; M. carpaticus; $N$. carpaticum; $N$. polonicum; $R$. transsilvanicus). Neobisium brevidigitatum has been reported from only one locality outside of the Carpathian Ranges and the Carpathian Basin, namely from Georgia (Kobakhidze 1966). In contrast, Neobisium crassifemoratum and $N$. fuscimanum show a trans-aegean distribution pattern.

It is important to mention that this study focused on a single area of the Carpathians and utilised material from a single collection only. Large parts of the North-Eastern Carpathians still have not been investigated, and the region is still understudied for pseudoscorpions. It is important to mention, that the present study is based principally on morphology. As we know the presence of cryptic speciation in some species of Neobisium (Śt'áhlavský 2003), molecular data may be used in the future to re-test the species hypotheses established here.

Considering also the pseudoscorpion fauna of the neighbouring areas, the occurrence of some further pseudoscorpion species are also expected: Chthonius (C.) hungaricus Mahnert, 1980; Neobisium (N.) erythrodactylum (L. Koch, 1873); Roncus lubricus L. Koch, 1873; Dactylochelifer latreillii (Leach, 1817); Chernes montigenus (Simon, 1879); Dinocheirus panzeri C. L. Koch, 1837; Pselaphochernes scorpioides (Hermann, 1804).

It is worth noting that this region has been part of five different countries over the course of the last century [Austro-Hungarian Monarchy (1918); Czechoslovakia and Poland (1918-1939); Hungary (1939-1945); Soviet Union (1945-1991) and finally Ukraine (1991-)], which makes the search and study of relevant literature a complicated task. These difficulties may be reflected in the relevant world catalogues and keys that sometimes omit the data for species occurring here (Beier 1963, Harvey 2013).

In the light of these considerations, adding to the catalogue of Harvey (2013) R. peculiaris (Daday 1888), N. fuscimanum and L. chyzeri (Szent-Ivány 1941) and the new data presented here the up-to-date species number recorded for Ukraine is twenty-six. 
Acknowledgements. The author would like to thank all collectors of the examined material. I am also grateful to Dr. Klára Dózsa-Farkas for her useful advices and to Dr. László Dányi for making accessible the pseudoscorpion material of the HNHM.

\section{REFERENCES}

BEIER, M. (1928): Die Pseudoscorpione des Wiener Naturhistorischen Museums. I. Hemictenodactyli. Annalen des Naturhistorischen Museums in Wien, 42: 285-314.

BEIER, M. (1963): Ordnung Pseudoscorpionidea (Afterskorpione). Bestimmungsbücher zur Bodenfauna Europas, 1. Akademie-Verlag, Berlin, 313 pp.

Christophoryová, J., ŠŤÁhlavskÝ, F. \& Fedor, P. (2011): An updated identification key to the pseudoscorpions (Arachnida: Pseudoscorpiones) of the Czech Republic and Slovakia. Zootaxa 2876: 3548.

DADAY, E. (1888): A Magyar Nemzeti Múzeum álskorpióinak áttekintése. Természetrajzi Füzetek, 11: 111-136, 165-192.

GARDINI, G. (2014): The species of the Chthonius heterodactylus group (Arachnida, Pseudoscorpiones, Chthoniidae) from the eastern Alps and the Carpathians. Zootaxa, 3887(2): 101-137. doi: 10.11646/zootaxa.3887.2.1

HADŽI, J. (1939): Pseudoskorpione aus Karpathenrussland. Věstnik Československé Zoologické Společnosti v Praze, 6-7: 183-208.

HARVEY M.S. (2013): Pseudoscorpions of the World, version 3.0. Western Australian Museum, Perth. http://museum.wa.gov.au/catalogues-beta/pseudoscor pions (accessed 02 December 2016).

KÁRPÁTHEGYI, P. (2006): Két ritka álskorpió [Atemnus politus (Simon, 1878) és Chthonius heterodactylus Tömösvári, 1883] hazai elöfordulásai. Folia Historico Naturalia Musei Matraensis, 30: 115-116.
KOBAKHIDZE, D. (1965): Ecological and zoogeographical characteristics of Pseudoscorpionidea from Georgian SSR. Revue de d'Ecologie et Biologie du Sol, 2: 541-543.

MAHNERT, V. (2004): Die Pseudoskorpione Österreichs (Arachnida, Pseudoscorpiones). Denisia, 12: 459-471.

MRÁZ, P. \& RoNIKIER, M. (2016): Biogeography of the Carpathians: evolutionary and spatial facets of biodiversity. Biological journal of the Linnean Society, 119: 528-559. doi: 10.1111/bij.12918

NovÁK, J. (2015): New records for the pseudoscorpion-fauna of the Bakony Mts, Hungary (Arachnida: Pseudoscorpiones). Opuscula Zoologica, 46(2): 153-158. doi: 10.18348/opzool.2015.2.153

NOVÁK, J. \& HÖRWEG, C. (2016): Redescriptions of three species of the genus Neobisium J.C. Chamberlin, 1930 from the Balkans and the Carpathians (Arachnida: Pseudoscorpiones). Acta Zoologica Academiae Scientiarium Hungaricae (in print).

RAFALSKI, J. (1937): Neobisium (Neobisium) polonicum nov. spec, Nowy gatunek zaleszczotka (Pseudoscorpionidae). Poznanskie Towarzystwo Przyjaciól Nauk, Prace Komisji Matematyczno-przyrodniczej, Seria B, 8(5): 1-14.

SCHAWALLER, W. (1989): Pseudoskorpione aus der Sowjetunion, Teil 3 (Arachnida: Pseudoscorpiones). Stuttgarter Beiträge zur Naturkunde (A), 440: $1-30$.

ŠŤÁHLAVSK, F., TŮMOVÁ P. \& KRÁL J. (2003): Karyotype analysis in central European pseudoscorpions of the genus Neobisium (Pseudoscorpiones: Neobisiidae). In. Kipyatkov V.E. \& Logunov D.V. (Eds.) 21st European Colloquium of Arachnology. St. Petersburg, 4.-9.8.2003. Abstract book. Russia, St. Petersburg, 80 pp.

SzENT-IVÁNY, J. (1941): Neue Angaben zur Verbreitung der Pseudoscorpione im Karpatenbecken. Fragmenta Faunistica Hungarica, 4(1-4): 85-90. 